\title{
Improvement of the secular variation curve of the geomagnetic field in Egypt during the last 6000 years
}

\author{
Hatem Odah* \\ Institute for Study of the Earth's Interior, Okayama University, Misasa, Tottori-ken 682-0193, Japan \\ (Received July 14, 1999; Revised October 28, 1999; Accepted November 1, 1999)
}

\begin{abstract}
A total of 115 ceramic specimens out of 41 samples from 9 archeological sites in Giza, Fayoum, Benisuef, El Minia, Malawy, and Sohag were collected. They represent 14 well-determined ages covering the last 6000 years. Rock magnetic properties such as Curie temperature and hysteresis loops have been measured for these samples to identify the magnetic carrier; it is found to be fine-grained magnetite. All specimens were investigated using the classic Thellier double heating technique (Thellier and Thellier, 1959) and the modification after Odah et al. (1995) to obtain the paleointensity data. These paleointensities and the previous results of Odah et al. (1995) were used to improve the secular variation curve of the geomagnetic field in Egypt for the last 6000 years. This curve shows a maximum of $72.8 \mu \mathrm{T}$ at about $250 \mathrm{AD}$ and a minimum of $33 \mu \mathrm{T}$ at about $3500 \mathrm{BC}$. It also shows a general decrease of the magnetic moment during the last 2000 years.
\end{abstract}

\section{Introduction}

Egypt, with its long and well-documented history, provides well-dated archeological materials suitable for paleointensity studies. Previous paleointensity studies in Egypt were carried out by Athavale (1969), Games (1980), Hussain (1983, 1987), Aitken et al. (1984), Walton (1986), Odah (1993), and Odah et al. (1995). Odah et al. (1995) have constructed a preliminary secular variation curve for the geomagnetic field in Egypt for the time between $4000 \mathrm{BC}$ and 2000 AD. This curve contains only 13 ages and needs more measurements to be more acceptable. The results in this curve are based on applying the classic Thellier's (1959) double heating method with a certain modification to obtain reliable paleointensity data. The modification during the Thellier experiments is that the laboratory field is applied in the direction of the stable NRM (e.g., Rogers et al., 1979; Odah et al., 1995).

Several field trips have been carried out accompanying the archeologists and ceramists to a) West of Khofo and south east of Sphenix, Pyramids, Giza; b) Saqara, Giza; c) Fag El Gamous, Fayoum; d) Ahnasia, Benisuef; e) Beni Hasan, El Minia; f) Tona El Gabel, Malawy; g) Tell Al Amarana, Malawy; h) Atrebis, Sohag; and i) Abydos, Sohag. Only the homogeneously fired thick ceramic sherds were collected. Thin ceramics were avoided since they have anisotropy of magnetic susceptibility (Rogers et al., 1979). The ages of our samples were determined with a great accuracy by the Egyptian archeologists and the archeological foreign missions that excavate in the sites. The archeological sites, from which

*Permanent address: National Research Institute of Astronomy and Geophysics, Helwan, Cairo, Egypt.

Copy right (c) The Society of Geomagnetism and Earth, Planetary and Space Sciences (SGEPSS); The Seismological Society of Japan; The Volcanological Society of Japan; The Geodetic Society of Japan; The Japanese Society for Planetary Sciences. the samples were collected, have been thoroughly studied by many egyptologists and ceramicists (e.g., Boak, 1933; Bresciani, 1968; O'Connor, 1997 and others). 115 specimens out of 41 samples from 9 archeological sites (representing 14 well-dated ages) were collected. The sites are shown in Fig. 1 and listed in Table 1.

\section{Rock Magnetic Measurements}

For paleomagnetic and archeomagnetic studies, identification of the magnetic mineralogy of the samples helps to evaluate the intensity results. Two experiments have been undertaken to investigate the magnetic mineralogy of the ceramic samples. Thermomagnetic curves and hysteresis loops were measured on one sample from each site. The magnetic mineralogy of these ceramic samples is dominated by magnetite-type minerals.

In each sample, the magnetic mineral has a unique Curie temperature, so that the determination of this temperature is diagnostic of a specific kind of magnetic mineral. The thermomagnetic behaviour of the samples was investigated by measuring the magnetization of crushed sample in a strong field (about 0.7 Tesla) during thermal cycling from room temperature to $700^{\circ} \mathrm{C}$ and cooling back to room temperature. The Curie temperatures for these samples ranged from $570^{\circ} \mathrm{C}$ to $580^{\circ} \mathrm{C}$ which is typical of magnetite. The thermomagnetic curves do not show any chemical alterations during heating and both heating and cooling curves are very similar. This clearly shows that magnetite is stable up to high temperatures. Figure 2(a) shows the thermomagnetic curve of sample S7 from Saqara, Giza with Curie temperature of about $580^{\circ} \mathrm{C}$ indicating the presence of magnetite.

Room temperature hysteresis loops were measured using a vibrating sample magnetometer (VSM). All hysteresis loops indicate the presence of either a low coercivity phase ("magnetite-like" phase) reaching saturation in fields 
Table 1. Paleointensity measurements of the ceramic samples.

\begin{tabular}{|c|c|c|c|c|c|c|c|c|c|}
\hline \multirow{2}{*}{$\frac{\text { Age }}{2750 \mathrm{BC}}$} & \multirow{2}{*}{$\begin{array}{c}\text { Site } \\
\text { Saqara, Giza }\end{array}$} & \multirow{2}{*}{$\begin{array}{c}\text { Sample } \\
\text { S1 }\end{array}$} & \multicolumn{3}{|c|}{$F_{\text {specimen }}(\mu \mathrm{T})$} & \multirow{2}{*}{$\begin{array}{c}F_{\text {sample }}(\mu \mathrm{T}) \\
51.3\end{array}$} & \multirow{2}{*}{$\begin{array}{l}N \\
9\end{array}$} & \multirow{2}{*}{$\begin{array}{c}F_{\text {site }}(\mu \mathrm{T}) \\
51.5 \pm\end{array}$} & \multirow{2}{*}{$\frac{F_{\text {red }}(\mu \mathrm{T})}{50.2 \pm}$} \\
\hline & & & 51.3 & 51.1 & 51.5 & & & & \\
\hline \multirow[t]{2}{*}{ \pm 150} & $29.9^{\circ} \mathrm{N}, 31.2^{\circ} \mathrm{E}$ & S2 & 51.9 & 51.9 & 51.6 & 51.8 & & 0.26 & 0.26 \\
\hline & & S3 & 51.4 & 51.4 & 51.4 & 51.4 & & & \\
\hline $2650 \mathrm{BC}$ & S. E. Sphenix, & Sph1 & - & - & - & - & 9 & No & No \\
\hline \multirow{2}{*}{ \pm 100} & Pyramids, Giza & Sph2 & - & - & - & - & & results & results \\
\hline & $29.5^{\circ} \mathrm{N}, 31.1^{\circ} \mathrm{E}$ & Sph3 & - & - & - & - & & & \\
\hline $2625 \mathrm{BC}$ & Abydos, Sohag & $\mathrm{Ab} 1$ & 50.8 & 49.1 & 50.1 & 50.0 & 6 & $50.0 \pm$ & $51.2 \pm$ \\
\hline \pm 60.5 & $26.2^{\circ} \mathrm{N}, 31.9^{\circ} \mathrm{E}$ & $\mathrm{Ab} 2$ & 50.0 & 50.0 & 50.1 & 50.0 & & 0.0 & 0.0 \\
\hline $2500 \mathrm{BC}$ & Fag El Gamous, & $\mathrm{F} 1$ & 45.2 & - & 46.2 & 46.2 & 7 & $46.0 \pm$ & $45.2 \pm$ \\
\hline \multirow[t]{2}{*}{ \pm 100} & Fayoum & $\mathrm{F} 2$ & 46.3 & - & 46.0 & 46.1 & & 0.26 & 0.26 \\
\hline & $29.4^{\circ} \mathrm{N}, 31.0^{\circ} \mathrm{E}$ & F3 & 45.7 & 45.9 & 45.5 & 45.7 & & & \\
\hline $2295 \mathrm{BC}$ & West of Khofo & Kh1 & 54.0 & 52.0 & 53.0 & 53.0 & 9 & $52.2 \pm$ & $51.2 \pm$ \\
\hline \multirow[t]{2}{*}{ \pm 15} & Pyramids, Giza & $\mathrm{Kh} 2$ & 50.9 & 50.7 & 52.2 & 51.4 & & 0.8 & 0.8 \\
\hline & $29.5^{\circ} \mathrm{N}, 31.1^{\circ} \mathrm{E}$ & Kh3 & 52.2 & 52.4 & 52.3 & 52.2 & & & \\
\hline $2240 \mathrm{BC}$ & Saqara, Giza & S4 & 53.5 & 54.0 & 54.1 & 54.0 & 8 & $53.7 \pm$ & $52.4 \pm$ \\
\hline \multirow{2}{*}{ \pm 50} & $29.9^{\circ} \mathrm{N}, 31.2^{\circ} \mathrm{E}$ & S5 & 53.1 & 53.2 & 53.2 & 53.2 & & 0.44 & 0.44 \\
\hline & & S6 & 53.7 & - & 54.0 & 53.9 & & & \\
\hline $1958 \mathrm{BC}$ & Abydos, Sohag & Ab3 & 40.9 & 41.3 & 42.5 & 41.6 & 7 & $41.6 \pm$ & $42.6 \pm$ \\
\hline \multirow[t]{2}{*}{ \pm 172} & $26.2^{\circ} \mathrm{N}, 31.9^{\circ} \mathrm{E}$ & $\mathrm{Ab} 4$ & 41.5 & 41.3 & 41.8 & 41.5 & & 0.06 & 0.06 \\
\hline & & Ab5 & - & 41.55 & - & 41.6 & & & \\
\hline $1365 \mathrm{BC}$ & Tell Al Amarana, & Am1 & 66.0 & 67.0 & 65.7 & 66.2 & 9 & $67.5 \pm$ & $67.9 \pm$ \\
\hline \multirow[t]{2}{*}{ \pm 50} & Malawy & Am2 & 68.5 & 68.0 & 68.6 & 68.4 & & 1.14 & 1.14 \\
\hline & $27.6^{\circ} \mathrm{N}, 30.9^{\circ} \mathrm{E}$ & Am3 & 67.8 & 67.8 & 67.9 & 67.8 & & & \\
\hline $595 \mathrm{BC}$ & Saqara, Giza & S7 & 51.3 & 51.3 & 51.9 & 51.5 & 8 & $52.0 \pm$ & $50.7 \pm$ \\
\hline \multirow{2}{*}{ \pm 50} & $29.9^{\circ} \mathrm{N}, 31.2^{\circ} \mathrm{E}$ & S8 & 51.9 & 54.0 & 53.2 & 53.0 & & 0.84 & 0.84 \\
\hline & & S9 & 51.6 & 一 & 51.6 & 51.6 & & & \\
\hline $250 \mathrm{BC}$ & Beni Hasan, & $\mathrm{Bn} 1$ & 69.3 & 69.1 & 68.6 & 69.0 & 9 & $68.4 \pm$ & $68.5 \pm$ \\
\hline \multirow[t]{2}{*}{ \pm 25} & El Minia & $\mathrm{Bn} 2$ & 68.8 & 68.0 & 67.8 & 68.2 & & 0.49 & 0.49 \\
\hline & $27.9^{\circ} \mathrm{N}, 30.9^{\circ} \mathrm{E}$ & $\mathrm{Bn} 3$ & 68.2 & 67.8 & 68.2 & 68.1 & & & \\
\hline $250 \mathrm{AD}$ & Tona El Gabel, & To1 & 72.0 & 72.3 & 71.7 & 72.0 & 9 & $72.1 \pm$ & $72.3 \pm$ \\
\hline \multirow[t]{2}{*}{ \pm 50} & Malawy & To2 & 71.9 & 71.9 & 72.2 & 72.0 & & 0.17 & 0.17 \\
\hline & $27.8^{\circ} \mathrm{N}, 30.7^{\circ} \mathrm{E}$ & To3 & 72.3 & 72.6 & 72.0 & 72.3 & & & \\
\hline $550 \mathrm{AD}$ & Ahnasia, Benisuef & Ah1 & - & 57.9 & - & 57.9 & 7 & $57.7 \pm$ & $56.9 \pm$ \\
\hline \multirow[t]{2}{*}{ \pm 25} & $29.1^{\circ} \mathrm{N}, 30.9^{\circ} \mathrm{E}$ & Ah2 & 57.9 & 57.5 & 57.4 & 57.6 & & 0.15 & 0.15 \\
\hline & & Ah3 & 57.3 & 57.9 & 57.9 & 57.7 & & & \\
\hline $750 \mathrm{AD}$ & Atrebis, Sohag & At1 & 61.6 & 61.0 & 61.0 & 61.2 & 9 & $61.0 \pm$ & $62.2 \pm$ \\
\hline \multirow[t]{2}{*}{ \pm 25} & $26.5^{\circ} \mathrm{N}, 31.7^{\circ} \mathrm{E}$ & At2 & 61.0 & 61.1 & 61.5 & 61.2 & & 0.35 & 0.35 \\
\hline & & At3 & 60.8 & 60.7 & 60.3 & 60.6 & & & \\
\hline $950 \mathrm{AD}$ & Atrebis, Sohag & At4 & 52.5 & 52.5 & 53.0 & 52.7 & 9 & $53.0 \pm$ & $54.1 \pm$ \\
\hline \multirow[t]{2}{*}{ \pm 50} & $26.5^{\circ} \mathrm{N}, 31.7^{\circ} \mathrm{E}$ & At5 & 53.4 & 53.4 & 53.3 & 53.4 & & 0.35 & 0.35 \\
\hline & & At6 & 53.0 & 52.7 & 53.3 & 53.0 & & & \\
\hline
\end{tabular}

Where $F_{\text {specimen }}$ is the paleointensity measurement for each specimen, $F_{\text {sample }}$ is the mean paleointensity for $1-3$ specimens, $N$ is the number of specimens in the site, $F_{\text {site }}$ is the site mean paleointensity from 2-3 samples and $F_{\text {red. }}$ is the reduced site mean to the middle altitude of Egypt ( $28^{\circ} \mathrm{N}$ ). 


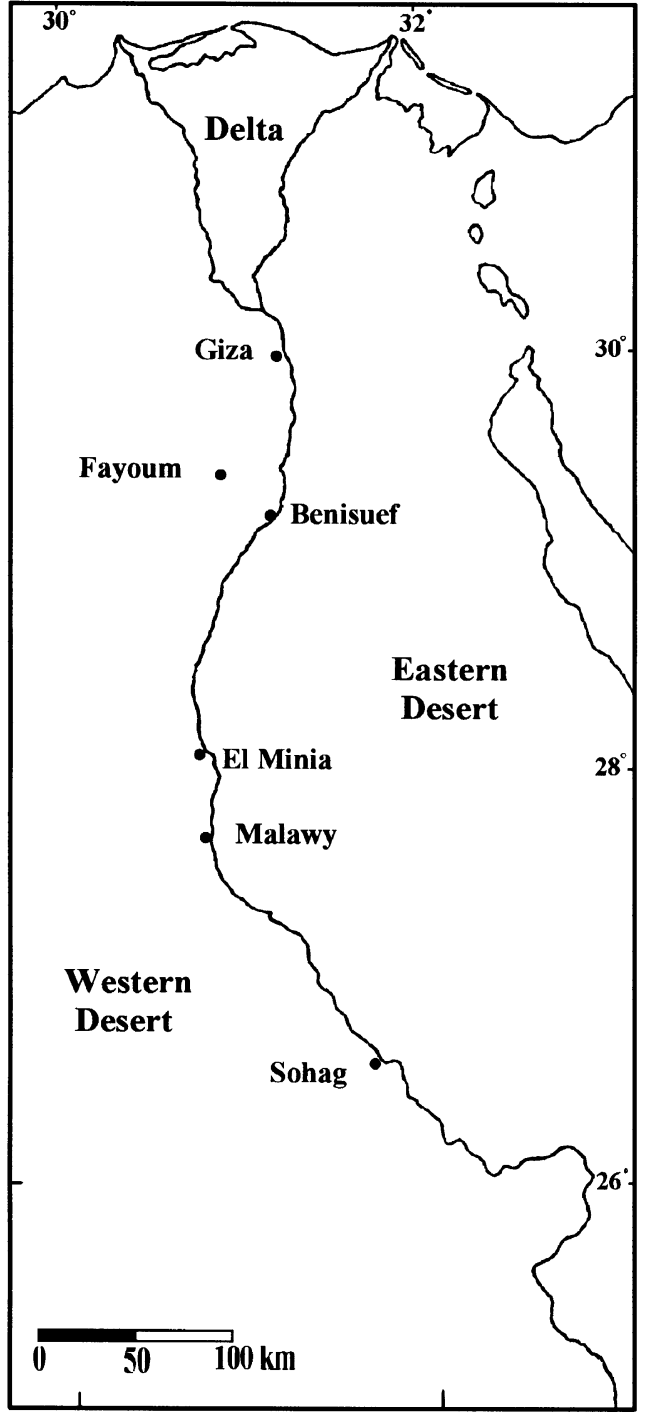

Fig. 1. Location map of the studied archeological areas.

of about 150-200 mT or the presence of high coercivity phase (hematite or geothite) reaching saturation in fields of about 500-700 $\mathrm{mT}$ and/or a paramagnetic phase. The hysteresis rock magnetic characteristics such as the saturation remanence $M_{r s}$ ranges from 0.02 to $1.7 \mathrm{Am}^{2} / \mathrm{kg}$, the ratio $M_{r s} / M_{s}$ ranges from 0.1 to 0.4 , and the coercive force $H_{c}$ ranges from 7 to $12 \mathrm{mT}$. This can be interpreted as a mixture of single domain (SD) and multidomain (MD) grains. Figure 2(b) shows a hystersis loop of sample S7 from Saqara, Giza. This loop indicates the presence of a low coercive phase ("magnetitelike" phase) reaching saturation in a field about $300 \mathrm{mT}$. The mean hysteresis parameters of this loop are: $M_{r s}$ of 0.21 , $M_{r s} / M_{s}$ of 0.34 and $H_{c}$ of $11.7 \mathrm{mT}$.

\section{Paleointensity Measurements}

All samples were prepared in the same way as in Odah et al. (1995) so that the cylinder axes of the specimens were oriented parallel to the direction of the stable NRM and therefore parallel to $F_{\text {Lab. }}$. This method together with the modification was used for the paleointensity determinations in this study. 115 specimens from 41 samples representing 14 well-dated
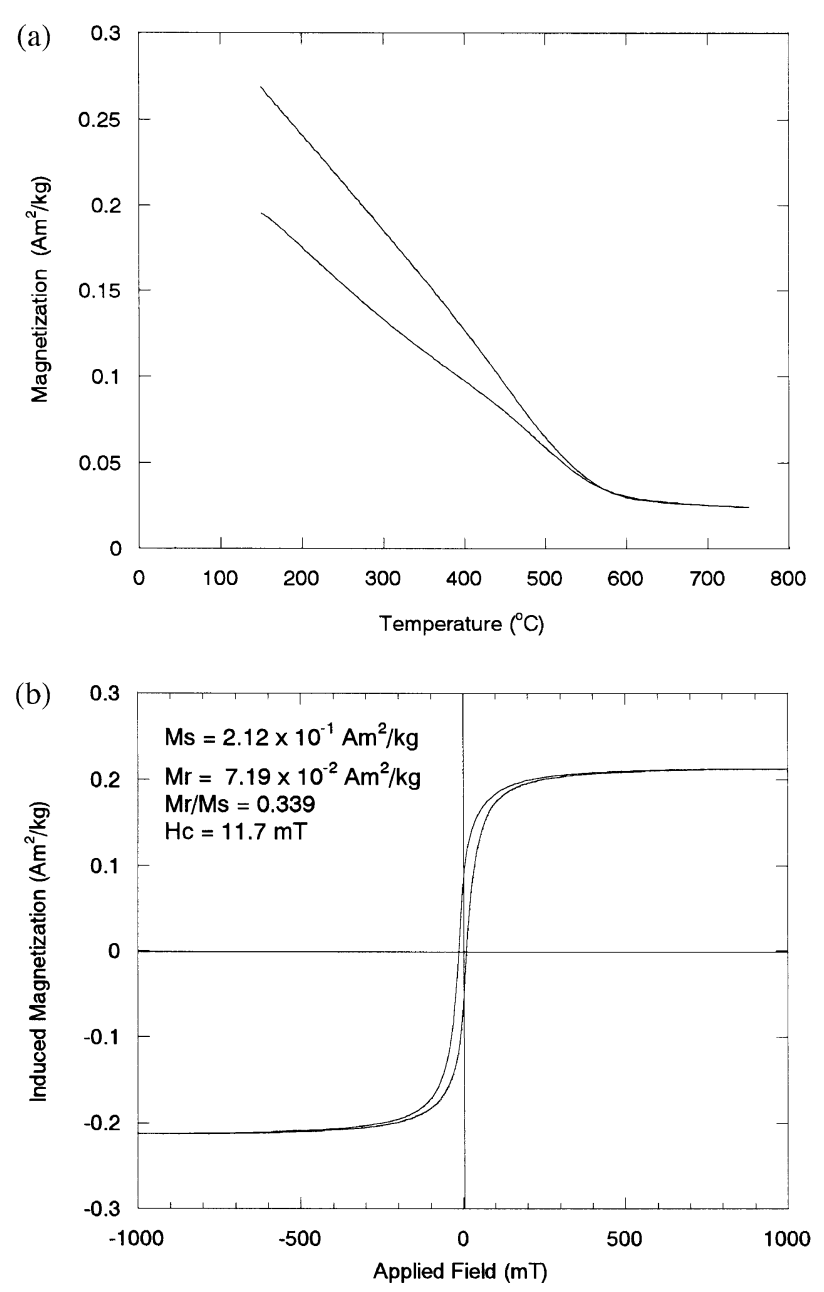

Fig. 2. Rock-magnetic measurements of sample S7 from Saqara, Giza: (a) Thermomagnetic curve with Curie temperature of about $580^{\circ} \mathrm{C}$ (magnetite) (b) Hystersis loop shows the presence of low coercive phase ("magnetite-like" phase).

ages were measured. The $F_{\text {Lab. }}$ during Thellier experiments was constant for all samples and equal to $50 \mu \mathrm{T}$.

In the case of the archeological materials, a common problem is the effect of weathering causing chemical changes. The Arai diagrams of most samples show a linear relationship over a large part of the entire temperature range. This means that there is no chemical alterations in our samples. Figures 3(a) and (b) show two Arai diagrams of NRM versus pTRM for samples Ab1-1 from Abydos, Sohag and S4-1 from Saqara, Giza. No cooling rate correction was applied to the data. The results of the paleointensity of the specimens, mean for sample, and mean for site from this work are listed in Table 1.

\section{Secular Variation Curve of the Geomagnetic Field in Egypt}

The behaviour of the earth's magnetic field through the archeological ages can be represented in the form of secular variation curve. Figure 4 represents a plot of the secular variation curve of the geomagnetic field through the archeological ages in Egypt for the time between $2750 \mathrm{BC} \pm 150$ and $950 \mathrm{AD} \pm 50$ based only on the determinations of the 


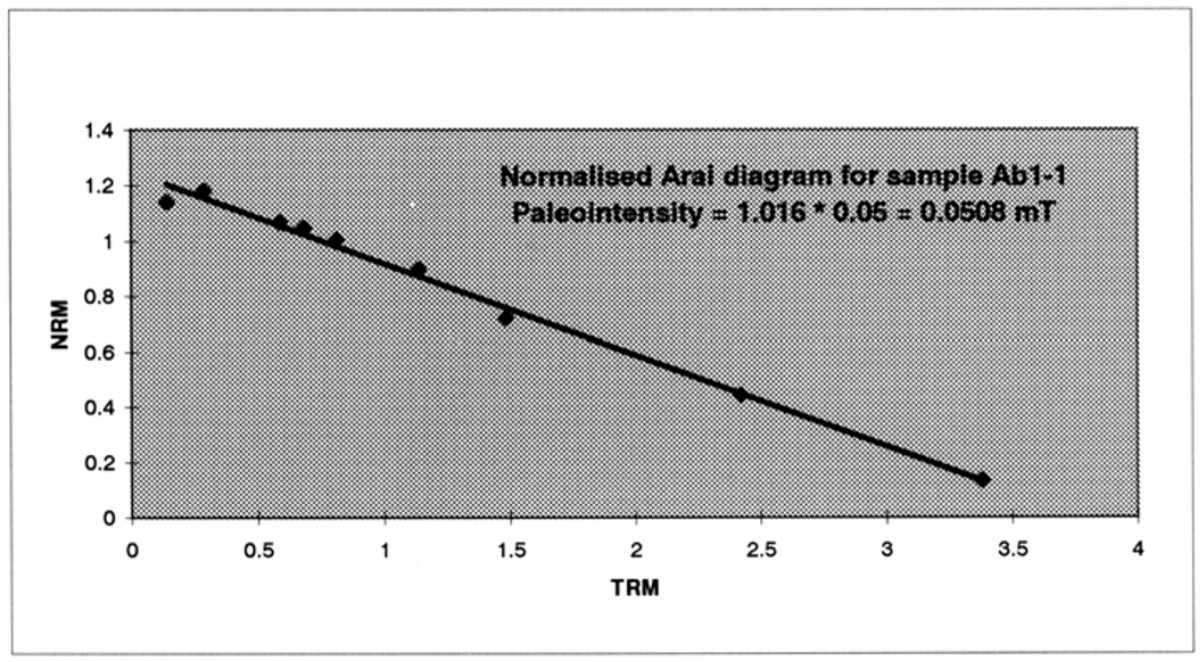

(a)

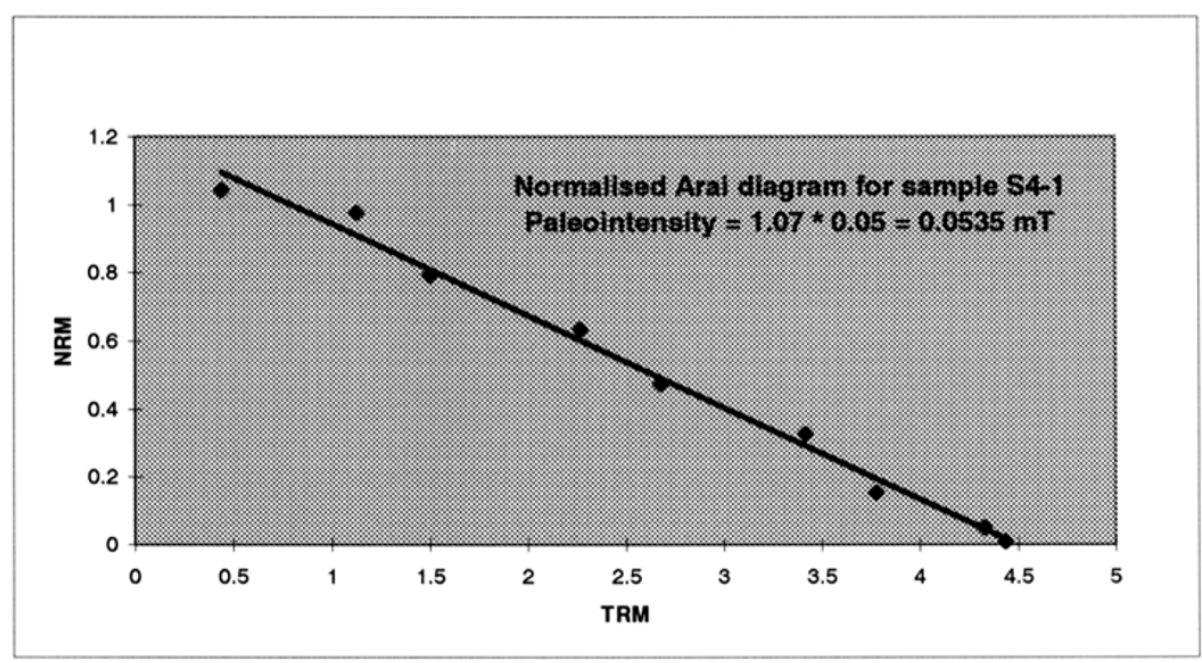

(b)

Fig. 3. Normalized Arai diagram for two sample: (a) sample Ab1-1 from Abydos, Sohag. (b) sample S4-1 from Saqara, Giza.

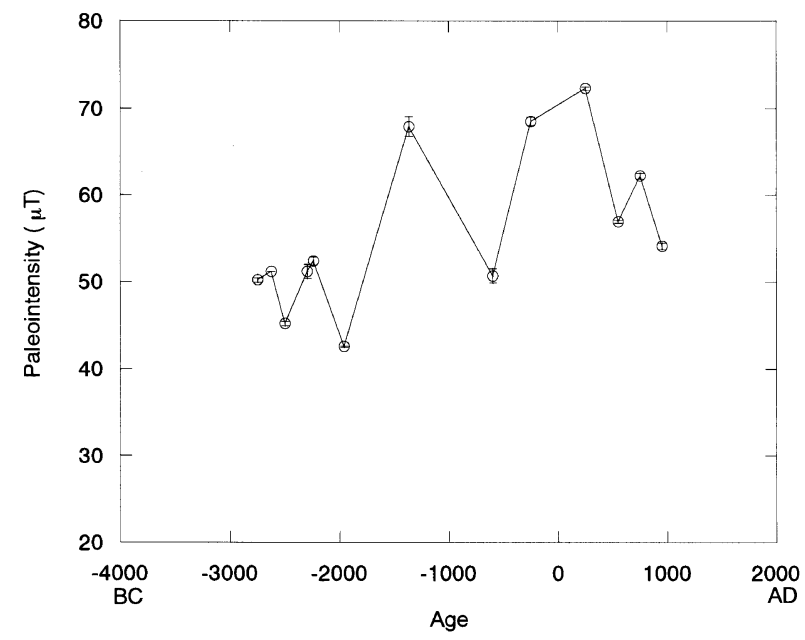

Fig. 4. Secular variation curve of the geomagnetic field in Egypt during the last 6000 years based only on the results of this study. The data are reduced to the middle latitude of Egypt. paleointensity from this study. The mean value of the ancient geomagnetic field for each site is reduced to the middle geographic latitude of Egypt $\left(28^{\circ} \mathrm{N}\right)$ according to the virtual axial dipole equation (Creer et al., 1983). The reduced mean value for each site $F_{\text {red. }}$ is plotted versus age starting with an intensity of $50.2 \mu \mathrm{T}$ at $2750 \mathrm{BC} \pm 150$ and ending with a 54.1 $\mu \mathrm{T}$ at $950 \mathrm{AD} \pm 50$. The curve shows a minimum value of a $42.6 \mu \mathrm{T}$ at about $1958 \mathrm{BC} \pm 172$ and the maximum values $67.9 \mu \mathrm{T}$ at $1365 \mathrm{BC} \pm 50$ and of 68.5 and $72.3 \mu \mathrm{T}$ between $250 \mathrm{BC} \pm 25$ and $250 \mathrm{AD} \pm 50$.

\section{Discussion and Conclusions}

Odah et al. (1995) carried out some rock magnetic and microscopic studies for the archeological ceramic samples from Egypt. These studies indicated that the main magnetic carrier is single to pseudo-single domain magnetite. The ceramic collection in this study has thermomagnetic curves and hysteresis loops (Figs. 2(a) and (b)) similar to that in Odah et al. (1995). This may indicates that magnetite is the main magnetic carrier in the archeological ceramics in Egypt. 


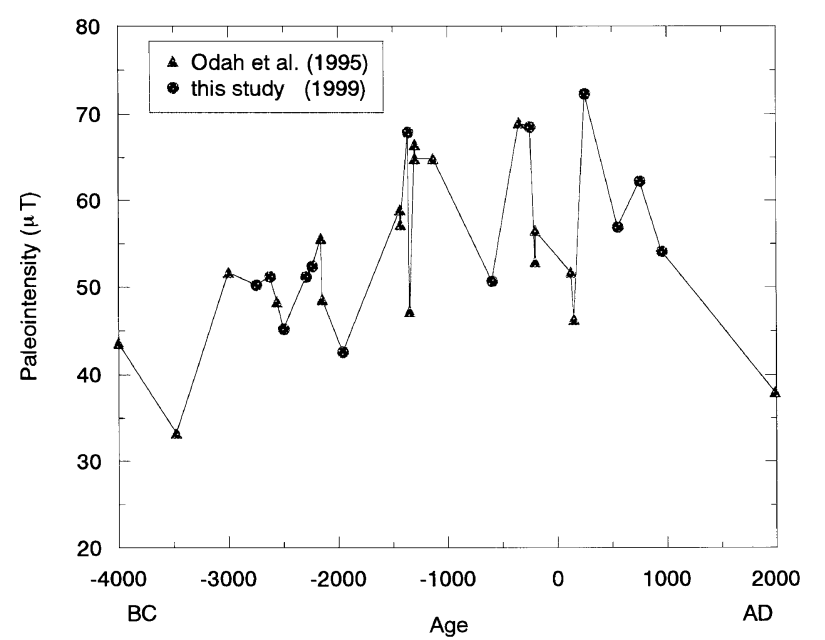

Fig. 5. Secular variation curve of the geomagnetic field in Egypt during the last 6000 years based on the results of this study together with the results of Odah et al. (1995). The data are reduced to the middle latitude of Egypt.

This result is typical for the baked earth that is usually used in Egyptian ceramics. The fine grains in the baked earth are usually totally oxidized during the manufacturing of the ceramics. No chemical alterations are thus expected during the Thellier double heating experiments. Thellier (1977) suggested that backed earth is the most suitable material for paleointensity determinations using the Thellier method.

The classic Thellier experiment (1959) with the modification of Odah et al. (1995) was used for paleointensity determinations. The external field was applied in the direction of the stable NRM. This cancels the effect of the magnetic anisotropy in the ceramic materials (Hussain, 1987; Odah et $a l .$, 1995). The paleointensity results from this study were plotted against age to show the secular variation of the geomagnetic field in Egypt during this period (Fig. 4). Figure 5 shows the secular variation curve of the geomagnetic field in Egypt for the last 6000 years based on the paleointensity determinations from the two studies (present study and Odah et al., 1995) after reduction to the middle latitude of Egypt. This curve starts with a field intensity of $43.6 \mu \mathrm{T}$ at $4000 \mathrm{BC}$ and ends with a field of $38 \mu \mathrm{T}$ at $1990 \mathrm{AD}$. This curve has minimum field intensity values of $33.3 \mu \mathrm{T}$ at about $3476 \mathrm{BC}$, of $42.6 \mu \mathrm{T}$ at $1958 \mathrm{BC} \pm 172$ and of $38 \mu \mathrm{T}$ at $1990 \mathrm{AD}$. The maximum field values are represented at about $1350 \mathrm{BC} \pm 50$
$(67.9 \mu \mathrm{T}), 250 \mathrm{BC} \pm 25(68.5 \mu \mathrm{T})$ and $250 \mathrm{AD} \pm 50(72.3$ $\mu \mathrm{T})$. This curve is suitable for archeomagnetic chronology because the $F_{\text {Lab. }}$ is parallel to the stable NRM and due to the accuracy of dating of the archeological ceramics. The results demonstrate the necessity of using such well-dated materials in paleointensity studies of the geomagnetic field to fill the gaps in this curve where more data are needed to define the curve more precisely.

Acknowledgments. The author wish to thank Prof. John Shaw, Geomagnetism Laboratory, University of Liverpool, United Kingdom for providing the instrument facilities during the research visit to England. Thanks also are offered to Prof. Masaru Kono, Institute for Study of the Earth's Interior, Misasa, Okayama University for revising the manuscripts.

\section{References}

Aitken, M. J., A. L. Allsop, G. D. Bussell, and M. B. Winter, Geomagnetic intensity in Egypt and Western Asia during the second millennium BC, Nature, 310, 305-306, 1984.

Athavale, R. N., Intensity of the geomagnetic field in prehistoric Egypt, Earth Planet. Sci. Lett., 6, 221-224, 1969.

Boak, A. E. R., The temples, coin hoards, botanical and zoological reports, seasons 1924-1931, Univ. Michigan Press, 1933.

Bresciani, E., Messione die scavo medint Madi, Rapporto preliminiare della campagne di scavo 1966 e 1967, 1968.

Creer, K. M., P. Tucholka, and C. E. Barton, Geomagnetism of Baked Clays and Recent Sediments, 324 pp., Elsevier, Amsterdam, 1983.

Games, K. P., The magnitude of the archeomagnetic field in Egypt between 3000 and 0 BC, Geophys. J. R. astr. Soc., 63, 45-56, 1980.

Hussain, A. G., Archeological investigation in Egypt: Inclination and field intensity determination, J. Geophys., 53, 131-140, 1983.

Hussain, A. G., The secular variation of the geomagnetic field in Egypt in the last 5000 years, Pageoph, 125, 67-90, 1987.

O'Connor, D., Report on Abydos: The Early Dynastic Project, pp. 1-5, New York University, 1997.

Odah, H., Archeomagnetic studies in some localities in A. R. Egypt, Ph.D. Thesis, Fac. of Sci. Mansoura University, 182 pp., Egypt, 1993.

Odah, H., F. Heider, A. G. Hussain, V. Hoffmann, H. Soffel, and M. ElGamili, Paleointensity of the geomagnetic field in Egypt from 4000 $\mathrm{BC}$ to $150 \mathrm{AD}$ using the Thellier method, J. Geomag. Geoelectr., 47, 41-58, 1995.

Rogers, J., J. M. W. Fox, and M. J. Aitken, Magnetic anisotropy in ancient pottery, Nature, 227, 644-655, 1979.

Thellier, E., Early research on the intensity of the ancient geomagnetic field, Phys. Earth Planet. Inter, 13, 241-244, 1977.

Thellier, E. and O. Thellier, Sur l'intensité du champ magnétique terrestre, en France, a l'epoque gallo-romaine, Compt. Rend., 222, 905-907, 1959.

Walton D., Alteration and its effects on the reproducibility of archaeomagnitudes from Tel-El-Amarana, J. Geomag. Geoelectr., 38, 1349-1352, 1986.

H. Odah (e-mail: hatem@misasa.okayama-u.ac.jp) 